A\&L

ISSN 2709-0205

Vol 2 Issue 3 (2021)

https://doi.org/10.47855/ja19020-2021-3

\title{
Pharmacology-based toxicity assessment of molsidomine and ATP-LONG combination with singular and repetitive injections under experimental conditions
}

\author{
L. P. Kuprash ${ }^{1}$, T. M. Panteleymonova ${ }^{1}$, L. B. Sharabura ${ }^{1}$, S. A. Mykhalskiy ${ }^{1}$, \\ P. P. Klymenko', S. P. Lugovskoy', V. M. Nepomnyashchy², N. V. Sykalo, \\ V. V. Bezrukov ${ }^{1}$ \\ ${ }^{1}$ D. F. Chebotarev Institute of Gerontology NAMS of Ukraine, Kyiv, Ukraine \\ ${ }^{2}$ Institute of Nephrology NAMS of Ukraine, Kyiv, Ukraine
}

https://doi.org/10.47855/jal9020-2021-3-1

Correspondence: panteleymonov01@ukr.net

Received: 24.09.2921; Accepted: 06.10.2021; Published: 06.10.2021

\begin{abstract}
The aim of the work was to study toxic properties of the new combined drug which comprise nitrovasodilator molsidomine and adenosine- 5'-triphosphate in a form of coordination compound with histidine, magnesium, and potassium (ATP-LONG).

The drug was examined for its acute and subacute toxicity on Balb/c mice and Wistar rats of reproductive age with peroral (p/o) and sublingual (s/l) administrations.

It has been established that $\mathrm{LD}_{50}$ of the substance contains over $10000 \mathrm{mg} / \mathrm{kg}(\mathrm{p} / \mathrm{o})$ and $5010 \mathrm{mg} / \mathrm{kg}(\mathrm{s} / \mathrm{l})$, which corresponds to the category of Practically non-toxic substances.

The repetitive administrations within a 28 day period of the conditionally therapeutic dose of $260 \mathrm{mg} / \mathrm{hg}$ (s/l) did not cause any negative impact on physiological, biochemical, histological values in male and female rats. In doses 1300 and $2080 \mathrm{mg} / \mathrm{kg}$, which exceed conditionally therapeutic doses by 5 and 8 times, the combination was not changing clinical laboratory urine and blood values but induced histological changes such as dilation and plethora of capillaries along with edema of smooth muscle cells of the brain, myocardium, liver, spleen, kidneys, and adrenal glands in rats. Additionally, the particular dosages of the combined substance provoked irritation of the mucous membrane of the tongue. Detected effects of the drug do not carry any pathological character and can be viewed as a specific reaction of the organism to high doses of nitrovasodilator. However, the duration and reversibility of unwanted consequences of molsidomine overdose, particularly in its combined form, need further investigation.
\end{abstract}

Keywords: combination of molsidomine and ATP-LONG, acute and subacute toxicity.

In order to improve methods of comprehensive treatment of patients with diseases of the cardiovascular system, especially the elderly, a new pharmacological combination was created, with adenosine-5'triphosphate (ATP-LONG) and molsidomine as active components. In medical practice, ATP drugs are grouped with the remedies affecting metabolism. ATP-LONG is one of such remedies, in which ATP is presented as a multiple ligand coordination compound, which includes ATP and histidine ligands in combination with $\mathrm{Mg}^{2+}$ and $\mathrm{K}^{+}$. According to the authors of the research, in this form an ATP molecule shows broader tropism to membrane purinoceptors, is less exposed to enzyme catalysis, as well as can easily participate in various metabolic processes, and affect cardiac function and energy supply $[1,2]$ first 
of all. Molsidomine is known as a sidnonimine nitric oxide donor, which has an antianginal effect and is important for the treatment of cardiovascular and other diseases [3, 4, 5].

A preclinical study of the specific activity of molsidomine in conjunction with ATP-LONG, performed on younger and spontaneously hypertensive lab animals, revealed vasodilator, cardio- and neurotropic, and antistress effects, thereby allowing the following combination to be used in geriatrics as a possible therapeutic and prophylactic cure [6,7]. The other equally important stage in preclinical studies of pharmaceuticals, including new combinations of already known bioactive substances, is the study of their toxicity.

Although ATP is an essential metabolite, its significant potential therapeutic effect, along with the other adenosine derivatives, is limited with side-effects like reduced cardiac function, arrhythmia, lower blood pressure, sedation, dyspnea, headache, hyperuricemia, when consistently applied $[8,9,10]$. The side effects are likely to be related to a wide range of various mechanisms, in which extracellular ATP, operating as a signaling molecule, is involved [11]. Driven by the activation of purinergic receptors contained on nerve, muscle, endothelial and other cell membranes of the body, ATP takes part in several neurotransmitter and neuromodulator processes in the central and peripheral nervous systems, as well as in regulating vasodilation [12], thereby arousing its multiple collateral effects, both positive and negative. In addition, the administration of ATP can cause hyperuricemia [13], considered a risk factor for metabolic syndrome, hypertension, chronic kidney disease, gout. Given the above, ATP medication is prescribed with caution for older adults.

Molsidomine, another component of the new combined drug, is a xenobiotic. In the liver, it undergoes metabolism into the active sidnonimine and linsidomine metabolites and releases nitric oxide (NO) [14]. To date, NO has been recognized to play a role in the modulation of vasorelaxation, regeneration of the endothelium, regulation of leukocyte chemotaxis, platelet adhesion; it also contributes to the regulation of neurotransmission, immunity, and enzyme activity [14, 15, 16]. In a free state, the molecule of nitric oxide has a short half-life (from 0.5 to 30 seconds) and is rapidly destroyed. However, $\mathrm{NO}$, when being surplus in a cell, can bind to proteins and peptides, be deposited, migrate to the intercellular space and the cells of other organs, and perform there a warning, protective or damaging action [17]. Almost all cell types have been proved to have nitric oxide metabolites involved in the endogenous antioxidant defense system mechanisms, and, at the same time, nitric oxide, depending on specific conditions and concentrations, can stimulate oxidation to be a potent prooxidant $[5,18]$. It is the concentration of nitric oxide is the main determinant of its biological effect: when NO concentration is low, a direct impact of nitric oxide for maintaining homeostasis of the cardiovascular and nervous systems predominates, while a higher concentration of nitric acid is followed by indirect effects related to the formation and subsequent impact of highly reactive peroxynitrite $[19,20]$. The latter can cause oxidative stress and take part in neurodegenerative processes [21], pathology of the cardiovascular and other body systems [22].

The biological effects of exogenous nitric oxide are mostly determined by its bioavailability and balance between the production of oxidized lipids and some other substances in the body under the influence of NO synthases on the one hand, and their tissue utilization or inactivation, involving superoxide radicals on the other [23]. In the early stages of molsidomine introduction, the pharmacokinetics parameters of the drug were studied, and the effective dose $(16 \mathrm{mg})$ was recommended for use in patients with coronary heart disease (CHD) [24]. Though it has been discovered that taking molsidomine in the target dose increases the frequency of side effects (a headache, vertigo, psychomotor retardation, nausea, orthostatic hypotension, thrombocytopenia, etc.) [5]. Out of all three groups (the patients who received a placebo, molsidomine $8 \mathrm{mg}$ and molsidomine $16 \mathrm{mg}$ per day, there have been side effects in $4.7 \%$; $5.4 \%$ and $6.9 \%$ respectively [25]. In Ukraine, in practice, molsidomine is most often prescribed at a dose of $2 \mathrm{mg}$ two times a day, which allows reducing the frequency of side effects but calls into question the effectiveness of therapy [26]. In this case, the advantage of the combination of molsidomine with ATP-long is the ability to achieve a higher vasodilatory effect at a lower dose of molsidomine, which has been proven in animal trials [7].

The recently found other side effects of molsidomine have not been listed in the instructions to the medication [27]. This would suggest that the spillover effects of molsidomine, as well as many properties of 
nitric oxide, have not been fully studied, while the research results often contradict one another, posing greater challenges to the practical application of the medication.

Therefore, despite nitric oxide, along with the purine nucleotide ATP, is a unique component of biological systems, and their modulation can provide new clinical strategies for the treatment of many diseases. Safety profiles of such drugs should be constantly evaluated in order to balance the risks and benefits of their use, including as part of a fixed pharmacological combination.

\section{Purpose of the study.}

Research of toxic properties and experimental assessment of the safety of a new combination of molsidomine with ATP-long in single and multiple drug administrations.

\section{Materials and methods.}

For preclinical studies, the FarCos pharmaceutical company (Ukraine) prepared test samples of the combination of molsidomine with ATP-long in pill form administered sublingually - one pill weighing 260 mg contains ATP-LONG $10 \mathrm{mg}$, molsidomine $2 \mathrm{mg}$.

Acute toxicity and multiple administrations toxicity studies (subacute toxicity) have been performed following the "Procedure for carrying out preclinical studying of medicines" [28] and guidelines [29]. Manipulations with animals were carried out in accordance with the rules of the European Convention for the Protection of Vertebrate Animals Used in Experimental Research and Other Scientific Purposes (Strasbourg, 2005).

The acute toxicity studies have been conducted on Balb/c mice (5-month-old females). For oral administration, a suspension was prepared from the tablet pill mix with the needed concentration based on $1 \%$ Tween 80 aqueous solution. The suspension was administered at the rate of $0.1 \mathrm{ml}$ per $10 \mathrm{~g}$ of body weight once; large doses were administered twice with an interval of $30 \mathrm{~min}$ [29]. When administered sublingually, the tablet pill mix in an individual dose was placed in the oral cavity of a mouse. The criterion of toxicity was the clinical picture of intoxication and the survival rate of animals during 14 days.

The subacute toxicity was studied on Wistar rats (7-month-old males and females), which were administered sublingually with three doses: conditionally therapeutic $-260 \mathrm{mg} / \mathrm{kg}$ (equal to a dose of ATPLONG $10 \mathrm{mg} / \mathrm{kg}$, molsidomine $2 \mathrm{mg} / \mathrm{kg}$ ); $1300 \mathrm{mg} / \mathrm{kg}$ and $2080 \mathrm{mg} / \mathrm{kg}$, exceeding the initial dose by 5 and 8 times, respectively. The suspension with the needed concentration based on $1 \%$ Tween 80 aqueous solution was administered at a rate of $0.1 \mathrm{ml} / 100 \mathrm{~g}$ body weight during 28 days. After completion of the administration term of the compound, the CNS functionality (locomotor and exploratory activity, the "open field" emotionality test) and the cardiovascular system (according to the electrocardiogram) of the animals have been assessed. Clinical and laboratory parameters of blood and urine were studied. Biochemical parameters have been identified by the spectrophotometry method with the use of basic sets of reagents "Felicite Diagnostics" (Ukraine), the concentration of electrolytes has been determined by the flame photometry method.

After the animals had been euthanized with ether anesthesia, the internal organs and tongue were removed for histological examination. Tissue slices were enshrined in $10 \%$ aqueous formalin solution, dehydrated in alcohols of ascending concentration and poured into paraffin (paraplast). Histological slices of organs, $5 \mu \mathrm{m}$ thick ( $4 \mu \mathrm{m}$ for the kidney), were stained with hematoxylin and eosin, with Schiff-iodic acid additional staining to the kidneys and Nissl (thionine with cresyl violet) - to the brain slices. The preparations were examined and photographed with Olympus BX51 microscope.

The statistical variance significance among the groups has been estimated using Student's t-test and Wilcoxon-Mann-Whitney $U$ test. The results are presented as mean values and average error $(\mathrm{M} \pm \mathrm{m})$, as well as the median $(\mathrm{Me})$, lower and upper quartiles $(\mathrm{Q} 1, \mathrm{Q} 3)$. The significant variance determined is $\mathrm{P}<$ 0.05 rate.

\section{Results and Discussion.}

It was found that the combination of molsidomine with ATP-LONG did not cause lethality in mice in the dose range from $2000 \mathrm{mg} / \mathrm{kg}$ to $5010 \mathrm{mg} / \mathrm{kg}$ (s / l). During the observation period, there have been no cases of mouse mortality or clinical symptoms of intoxication reported with the administration at doses of 
1260 to $10,000 \mathrm{mg} / \mathrm{kg}$. The medication LD50 indicator exceeds 5,010 mg/kg (s / 1), and 10,000 mg/kg (p / o), which closely corresponds to the non-toxic substances class [29].

Multiple drug administrations during 28 days at doses of 260, 1300, and $2080 \mathrm{mg} / \mathrm{kg}$ have not revealed any negative effect on the appearance, behavior, motor activity of male and female rats. A statistically significant increase in body weight compared to the baseline parameter has been reported on days 14, 21 and 28 in both control and experimental groups. The exception is the females which had been receiving the drug at a dose of $2080 \mathrm{mg} / \mathrm{kg}$, with a significant increase in body weight reported on the 7th day of the experiment.

Any negative impact of the combined drug on the CNS functional activity has not been identified, as evidenced by the "open field" test. Thus, the motor and exploratory activity indicators (number of squares intersections and number of upright postures) in females of the experimental groups did not differ from the control group. However, in experimental females who were administered the drug in medium and high doses, a longer latent period of the first move was reported. Such behavior (fading, immobility) indicates a stronger emotional response to a potentially dangerous environment. In males, regardless of the administered dose, such an effect was not noticed. The differences between males' and females' "open field" behavior attribute to different emotional responses and stress tolerance and are normally observed in intact animals as well.

The drug studied in the given timeline and doses applied did not change the myocardium bioelectrical activity of the animals. Therefore, the analysis of the electrocardiogram of the lab rats has shown that the wave R amplitude, the length of R-R, PQ, QRS, and Q-T intervals, as well as heartbeat rate in rats of all experimental groups, coincides with the control animals of relevant sex.

The molsidomine and ATP-LONG combination had not been significantly affecting the morphological blood composition of the lab rats. Fluctuations observed at a dose of $2080 \mathrm{mg} / \mathrm{kg}$ (increase in the number of erythrocytes, decrease in the percentage of segmental neutrophils and increase in the percentage of lymphocytes) was occurring within the seasonal norm for rats [30] (Table 1).

Table 1

\section{Morphological composition of blood of rats receiving a combination of molsidomine with ATP-LONG, Me(Q1...Q3)}

\begin{tabular}{|c|c|c|c|c|}
\hline \multirow[t]{2}{*}{ Indexes } & \multirow[t]{2}{*}{ Control } & \multicolumn{3}{|c|}{ Molsidomine + ATP-LONG, mg / kg } \\
\hline & & 260 & 1300 & 2080 \\
\hline \multicolumn{5}{|c|}{ Females } \\
\hline Erythrocytes, $x 10^{12} / 1$ & $7.8(7.1 \ldots 8.2)$ & $8.0(7.5 \ldots 8.4)$ & $8.2(7.3 \ldots 8.5)$ & $8.6(7.7 \ldots 8.8)$ \\
\hline Leukocytes, x1099 / & $6.9(6.7 \ldots 7.5)$ & $7.2(6.8 \ldots 7.4)$ & $7.1(7.0 \ldots .7 .3)$ & $7.2(6.8 \ldots 7.6)$ \\
\hline $\begin{array}{l}\text { Neutrophils } \\
\text { segmental, \% }\end{array}$ & $30(27 \ldots 31)$ & $29(26 \ldots 32)$ & $27(24 \ldots 30)$ & $25(23 \ldots .27)^{*}$ \\
\hline Eosinophils, $\%$ & $2(2 \ldots 3)$ & $2(1 \ldots 2)$ & $3(1 \ldots 3)$ & $2(1 \ldots 4)$ \\
\hline Monocytes, \% & $1(1 \ldots 2)$ & $2(1 . .3)$ & $3(1 \ldots 3)^{*}$ & $2(1 \ldots 3)$ \\
\hline Lymphocytes, $\%$ & $66(65 \ldots 8)$ & $67(64 \ldots 71)$ & $68(65 \ldots 70)$ & $69(67 \ldots 73)^{*}$ \\
\hline Stick core neutrophils, $\%$ & $1(0 \ldots 1)$ & $1(0 \ldots 1)$ & $0(0 \ldots 2)$ & $1(0 \ldots 3)$ \\
\hline \multicolumn{5}{|c|}{ Males } \\
\hline Erythrocytes, x1012 / 1 & $7.6(7.4 \ldots 7.8)$ & $7.5(7.2 \ldots .7 .9)$ & $7.6(7.2 \ldots 8.1)$ & $8.0(7.7 \ldots 8.2)^{*}$ \\
\hline Leukocytes, x109/1 & $7.1(6.7 \ldots 7.2)$ & $6.8(6.6 \div 7.4)$ & $7.0(6.9 \ldots .7 .2)$ & $7.2(6.5 \ldots 7.5)$ \\
\hline Neutrophils segmental, \% & $34(32 \ldots 36)$ & $31(30 \ldots 33) *$ & $31(30 \ldots 33)$ & $30(29 \ldots 36)^{*}$ \\
\hline Eosinophils, \% & $3(2 \ldots 4)$ & $2(1 \ldots 3)$ & $2(2 \ldots 3)$ & $2(1 \ldots 2)^{*}$ \\
\hline Monocytes, $\%$ & $1(1 \ldots 2)$ & $2(1 \ldots)$ & $2(1 \ldots 2)$ & $2(1 \ldots 3)$ \\
\hline Lymphocytes, \% & $61(59 \ldots 70)$ & $64(62 \ldots 67)$ & $64(62 \ldots 65)$ & $66(60 \ldots 68)$ \\
\hline Stick core neutrophils, \% & $1(0 \ldots 1)$ & $0(0 \ldots 2)$ & $1(0 \ldots 2)$ & $0(0 \div 0)^{*}$ \\
\hline
\end{tabular}

Note. ${ }^{*}-\mathrm{P}<0.05$ compared with the control of the corresponding sex. 
The preparation did not change main protein, carbohydrate, lipid, electrolyte metabolism indicators, along with the liver and kidneys functionality of both male and female lab rats, as evidenced by tables 2 and 3.

Table 2

Biochemical parameters of serum of rats receiving a combination of molsidomine with ATP-LONG $(M+m)$

\begin{tabular}{|c|c|c|c|c|}
\hline \multirow[t]{2}{*}{ Indexes } & \multirow[t]{2}{*}{ Control } & \multicolumn{3}{|c|}{ Molsidomine + ATP-LONG, mg / kg } \\
\hline & & 260 & 1300 & 2080 \\
\hline \multicolumn{5}{|c|}{ Females } \\
\hline Total protein, $\mathrm{g} / \mathrm{l}$ & $64.8 \pm 3.0$ & $63.2 \pm 1.6$ & $68.9 \pm 1.5$ & $71.1 \pm 3.0$ \\
\hline Albumin, g / 1 & $34.0 \pm 1.1$ & $34.4 \pm 1.2$ & $34.3 \pm 1.0$ & $33.3 \pm 1.0$ \\
\hline Glucose, mmol / 1 & $4.8 \pm 0.1$ & $4.8 \pm 0.1$ & $4.8 \pm 0.1$ & $4.7 \pm 0.1$ \\
\hline Creatinine, $\mathrm{mkmol} / \mathrm{l}$ & $6.5 \pm 7.1$ & $67.8 \pm 6.9$ & $64.3 \pm 9.1$ & $61.0 \pm 6.8$ \\
\hline Urea, mmol / 1 & $4.4 \pm 0.32$ & $4.6 \pm 0.1$ & $4.5 \pm 0.1$ & $4.3 \pm 0.2$ \\
\hline Total lipids, g/ 1 & $6.91 \pm 0.42$ & $5.72 \pm 0.39$ & $6.12 \pm 0.52$ & $6.10 \pm 0.47$ \\
\hline Cholesterol, $\mathrm{mmol} / \mathrm{l}$ & $1.43 \pm 0.14$ & $1.27 \pm 0.16$ & $1.36 \pm 0.18$ & $1.37 \pm 0.15$ \\
\hline ALT, mkmol / (h. ml) & $2.08 \pm 0.14$ & $1.90 \pm 0.20$ & $1.75 \pm 0.12$ & $1.75 \pm 0.14$ \\
\hline AST, mkmol / (h. ml) & $1.40 \pm 0.27$ & $1.11 \pm 0.15$ & $1.48 \pm 0.29$ & $1.57 \pm 0.20$ \\
\hline Bilirubin, mkmol / 1 & $5.3 \pm 0.6$ & $4.8 \pm 0.6$ & $5.0 \pm 0.7$ & $5.2 \pm 0.6$ \\
\hline Thymol test, S-H unit & $1.3 \pm 0.2$ & $1.6 \pm 0.1$ & $1.4 \pm 0.2$ & $1.3 \pm 0.1$ \\
\hline Potassium, mmol / 1 & $4.8 \pm 0.3$ & $4.9 \pm 0.2$ & $4.6 \pm 0.3$ & $4.5 \pm 0.1$ \\
\hline Sodium, mmol / 1 & $146.2 \pm 1.0$ & $146.0 \pm 0.7$ & $144.9 \pm 2.5$ & $144.7 \pm 1.6$ \\
\hline \multicolumn{5}{|c|}{ Males } \\
\hline Total protein, g / l & $64.7 \pm 3.6$ & $73.6 \pm 3.5$ & $70.6 \pm 5.9$ & $72.9 \pm 1.4$ \\
\hline Albumin, g / 1 & $29.7 \pm 1.63$ & $30.2 \pm 1.46$ & $31.1 \pm 1.47$ & $30.6 \pm 1.3$ \\
\hline Glucose, mmol / 1 & $4.7 \pm 0.4$ & $4.7 \pm 0.4$ & $4.9 \pm 0.4$ & $4.6 \pm 0.4$ \\
\hline Creatinine, $\mathrm{mkmol} / \mathrm{l}$ & $64.3 \pm 8.8$ & $60.5 \pm 7.1$ & $59.6 \pm 5.8$ & $65.4 \pm 6.1$ \\
\hline Urea, $\mathrm{mmol} / \mathrm{l}$ & $4.6 \pm 0.4$ & $4.6 \pm 0.4$ & $4.3 \pm 0.2$ & $4.4 \pm 0.2$ \\
\hline Total lipids, g/ 1 & $8.4 \pm 0.9$ & $7.8 \pm 1.3$ & $7.3 \pm 0.6$ & $8.3 \pm 0.6$ \\
\hline Cholesterol, $\mathrm{mmol} / \mathrm{l}$ & $1.66 \pm 0.19$ & $1.76 \pm 0.09$ & $1.54 \pm 0.18$ & $1.61 \pm 0.13$ \\
\hline ALT, mkmol / (h. ml) & $2.31 \pm 0.09$ & $2.24 \pm 0.11$ & $2.16 \pm 0.11$ & $2.21 \pm 0.10$ \\
\hline AST, mkmol / (h. ml) & $1.81 \pm 0.08$ & $1.87 \pm 0.10$ & $1.62 \pm 0.10$ & $1.80 \pm 0.09$ \\
\hline Bilirubin, mkmol / 1 & $5.0 \pm 0.9$ & $5.4 \pm 0.6$ & $4.6 \pm 0.7$ & $5.0 \pm 0.7$ \\
\hline Thymol test, S-H unit & $1.5 \pm 0.2$ & $1.2 \pm 0.2$ & $1.7 \pm 0.2$ & $1.3 \pm 0.3$ \\
\hline Potassium, mmol / 1 & $4.2 \pm 0.1$ & $4.6 \pm 0.2$ & $4.3 \pm 0.2$ & $4.4 \pm 0.1$ \\
\hline Sodium, mmol / 1 & $138.3 \pm 2.0$ & $141.3 \pm 2.1$ & $142.6 \pm 2.0$ & $144.0 \pm 1.4$ \\
\hline
\end{tabular}

Note. In all cases, compared with the corresponding control $\mathrm{P}>0.05$. 
Table 3

Biochemical composition of urine of rats treated with a combination of molsidomine and ATP-LONG $(M \pm m)$

\begin{tabular}{|c|c|c|c|c|}
\hline \multirow[t]{2}{*}{ Indexes } & \multirow[t]{2}{*}{ Control } & \multicolumn{3}{|c|}{ Molsidomine + ATP-LONG, mg / kg } \\
\hline & & 260 & 1300 & 2080 \\
\hline \multicolumn{5}{|c|}{ Females } \\
\hline Diuresis, $\mathrm{ml} / 3$ hours & $2.9 \pm 0.4$ & $3.2 \pm 0.2$ & $2.7 \pm 0.2$ & $3.0 \pm 0.2$ \\
\hline Urine $\mathrm{pH}$ & $6.8 \pm 0.2$ & $6.8+0.2$ & $6.9 \pm 0.1$ & $6.8 \pm 0.2$ \\
\hline Glucose, $\%$ & 0 & 0 & 0 & 0 \\
\hline Acetone test, $\mathrm{mmol} / \mathrm{l}$ & 0 & 0 & 0 & 0 \\
\hline Protein, g/ 1 & $0.32 \pm 0.06$ & $0.27 \pm 0.05$ & $0.31 \pm 0.05$ & $0.35 \pm 0.05$ \\
\hline Creatinine, $\mathrm{mkmol} / \mathrm{l}$ & $6877 \pm 733$ & $7379 \pm 580$ & $7184 \pm 963$ & $6931 \pm 1089$ \\
\hline Uric acid, mmol / 1 & $793.2 \pm 112$ & $707.2 \pm 57.4$ & $591.3 \pm 67.4$ & $775.2 \pm 97.3$ \\
\hline Urea, mmol / 1 & $296.7 \pm 8.3$ & $305.6 \pm 6.0$ & $312.6 \pm 10.0$ & $313.6 \pm 21.1$ \\
\hline Potassium, $\mathrm{mmol} / \mathrm{l}$ & $23.2 \pm 0.9$ & $22.0 \pm 3.2$ & $22.4 \pm 1.1$ & $22.4 \pm 1.3$ \\
\hline Sodium, $\mathrm{mmol} / \mathrm{l}$ & $50.6 \pm 4.1$ & $43.6 \pm 1.8$ & $49.2 \pm 0.6$ & $46.0 \pm 2.4$ \\
\hline \multicolumn{5}{|c|}{ Males } \\
\hline Diuresis, $\mathrm{ml} / 3$ hours & $3.3 \pm 0.2$ & $2.9 \pm 0.1$ & $3.4 \pm 0.2$ & $3.5 \pm 0.3$ \\
\hline Urine $\mathrm{pH}$ & $6.8 \pm 0.1$ & $6.8 \pm 0.1$ & $6.9 \pm 0.1$ & $6.7 \pm 0.1$ \\
\hline Glucose, $\%$ & 0 & 0 & 0 & 0 \\
\hline Acetone test, $\mathrm{mmol} / \mathrm{l}$ & 0 & 0 & 0 & 0 \\
\hline Protein, g/ 1 & $0.37 \pm 0.05$ & $0.40 \pm 0.05$ & $0.44 \pm 0.05$ & $0.48 \pm 0.07$ \\
\hline Creatinine, $\mathrm{mkmol} / \mathrm{l}$ & $6084 \pm 968$ & $7451 \pm 798$ & $6637 \pm 1176$ & $5808 \pm 899$ \\
\hline Uric acid, mmol / 1 & $793.2 \pm 112$ & $707.2 \pm 57.4$ & $751.3 \pm 67.4$ & $775.2 \pm 97.3$ \\
\hline Urea, mmol / 1 & $690.0 \pm 120.1$ & $930.2 \pm 98.2$ & $750.1 \pm 113.0$ & $690.3 \pm 105.0$ \\
\hline Potassium, $\mathrm{mmol} / \mathrm{l}$ & $24.8 \pm 2.1$ & $25.2 \pm 3.1$ & $23.0 \pm 1.8$ & $27.0 \pm 0.3$ \\
\hline Sodium, mmol / 1 & $48.8 \pm 2.6$ & $54.8 \pm 1.8$ & $50.4 \pm 0.8$ & $43.8 \pm 1.1$ \\
\hline
\end{tabular}

Note. In all cases, compared with the corresponding control $\mathrm{P}>0.05$.

The doses administered of the molsidomine and ATP-LONG combination influence the absolute and relative weight of the brain, myocardium, liver, lungs, kidneys, and spleen, have not been reported in the male and female rats. However, in the males administered at a dose of $2080 \mathrm{mg} / \mathrm{kg}$, there was an increase in the absolute and relative weight of the adrenal glands, while in the females this figure did not change.

According to the results of histological examinations of internal organs (brain, myocardium, liver, spleen, kidneys, adrenal glands) of the rats receiving the molsidomine and ATP-LONG combination at a dose of $260 \mathrm{mg} / \mathrm{kg}$, no toxic effects were detected. In the animals administered at a dose of $1300 \mathrm{mg} / \mathrm{kg}$ and $2080 \mathrm{mg} / \mathrm{kg}$, in the myocardium swelling in the cytoplasm and middle membrane (media) single smooth muscle cells nuclei of the arteries have been noticed, particularly in the left ventricle of the males and females (Fig. 1). 


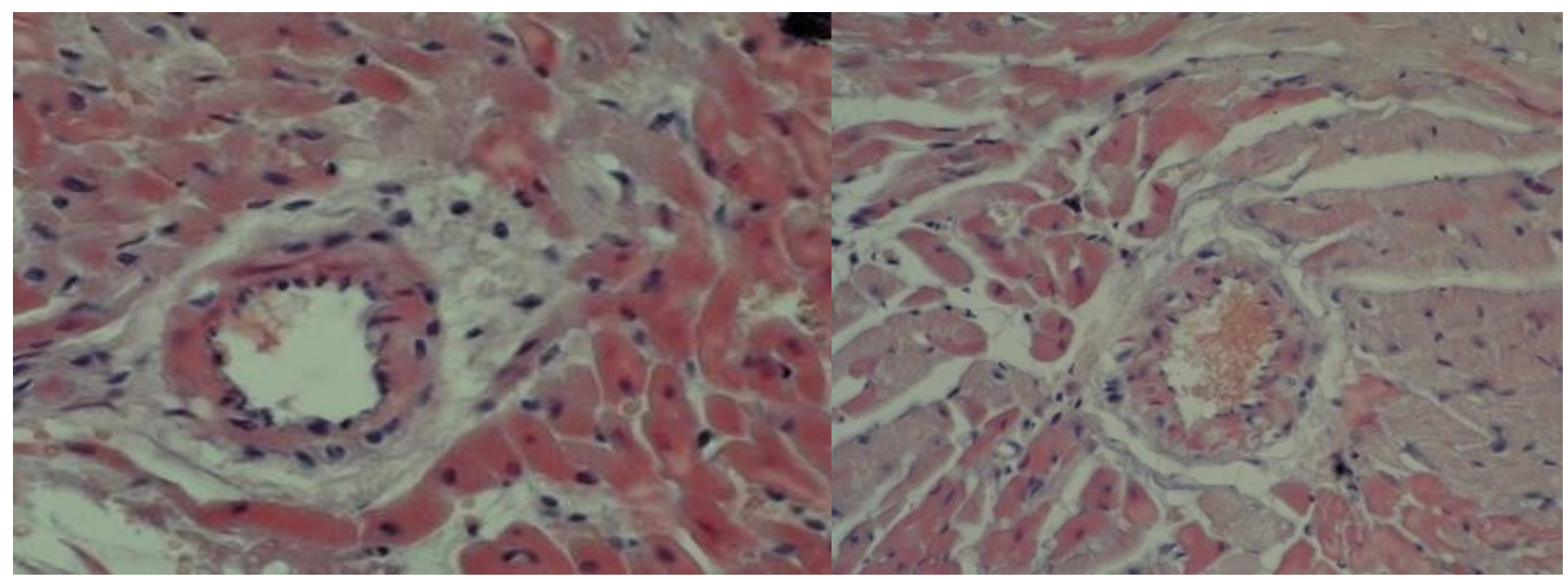

a)

b)

Figure 1. a) The area of the left ventricular myocardium of a male rat after administration of a combination of molsidomine with ATP-LONG at a dose of $1300 \mathrm{mg} / \mathrm{kg}$ - the artery wall is not changed, there is swelling of the cytoplasm of single smooth muscle cells; b) The area of the left ventricular myocardium of a female rat receiving the drug at a dose of $2080 \mathrm{mg} / \mathrm{kg}$ - there is swelling of the cytoplasm of smooth muscle cells the inartery wall. Hematoxylin and eosin, $x 400$ magnification.

Swelling of single smooth muscle cells of the middle lining of the arteries and periodically swelling of the loose connective tissue cells of the wall of some bile ducts have also been observed in the triads of the liver.

Examination of the spleen of the male and female rats after administration of the medication at doses of 1300 and $2080 \mathrm{mg} / \mathrm{kg}$ has revealed significant, compared with control indicators, the plethora of sinusoidal capillaries of the red pulp, as well as plethora of trabecular veins. In addition, after administration of the drug at a dose of $2080 \mathrm{mg} / \mathrm{kg}$ in the spleen of the animals amid the noticeable plethora of red pulp hypertrophy of white pulp was frequently seen, wherein the central B-zone of lymph nodes dense basophilic apoptotic bodies were found, which may indicate a modest effect on Blymphocytes due to the high doses of the compound (Fig. 2).

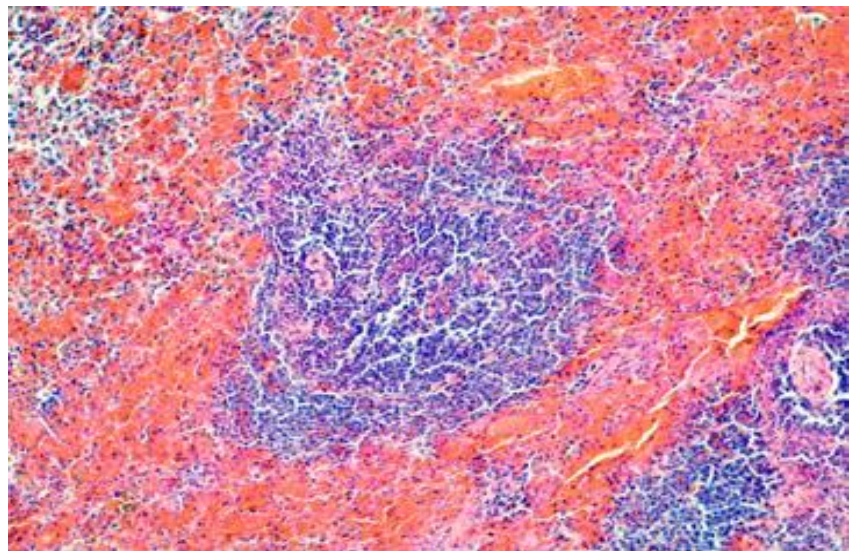

a) x 100 magnification

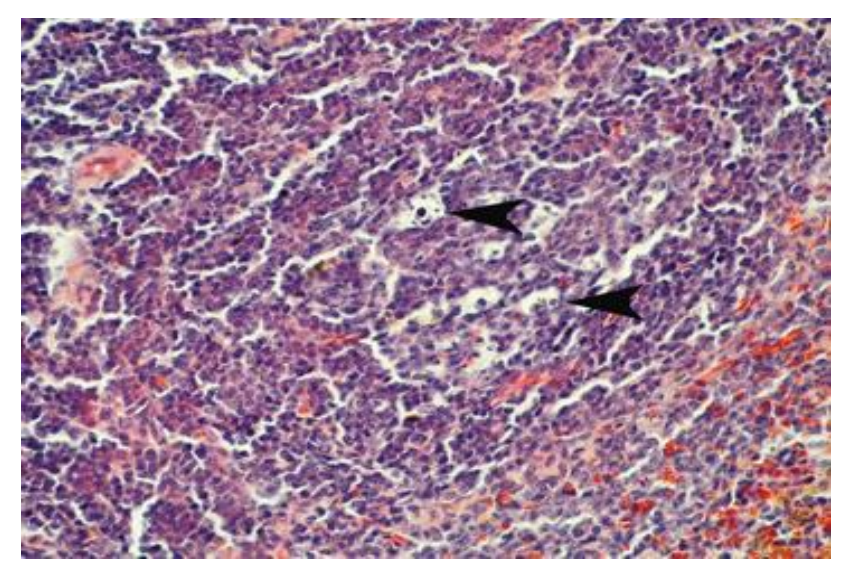

b) x 200 magnification

Figure 2. Histological changes in the spleen of rats after administration of a combination of molsidomine with ATP-LONG: a) at a dose of $1300 \mathrm{mg} / \mathrm{kg}$ - plethora of sinusoidal capillaries of the red pulp of trabecular veins; b) at a dose of $2080 \mathrm{mg} / \mathrm{kg}$ - dense apoptotic bodies in the central Bzone of the lymphatic follicle of the white pulp of the spleen $(\leftarrow)$. Hematoxylin and eosin. 
Histological examination of kidneys of the rats which had been receiving the molsidomine and ATP-LONG in three doses did not reveal specific signs of organ damage. The average thickness of the cortex and the numerical density of the glomeruli did not differ considerably between the control and experimental groups. In some animals of both sexes, there were only nonspecific changes reported: minor accumulation in the epithelium of individual tortuous tubules of granules of yellow-brown pigment lipofuscin (most animals from all groups), slight focal mononuclear infiltration of the cortical interstitium, rarely associated with atrophy of individual canals, and also the presence of mainly brain substance of PAS-positive protein - uromodulin in single tubules (Fig. 3).

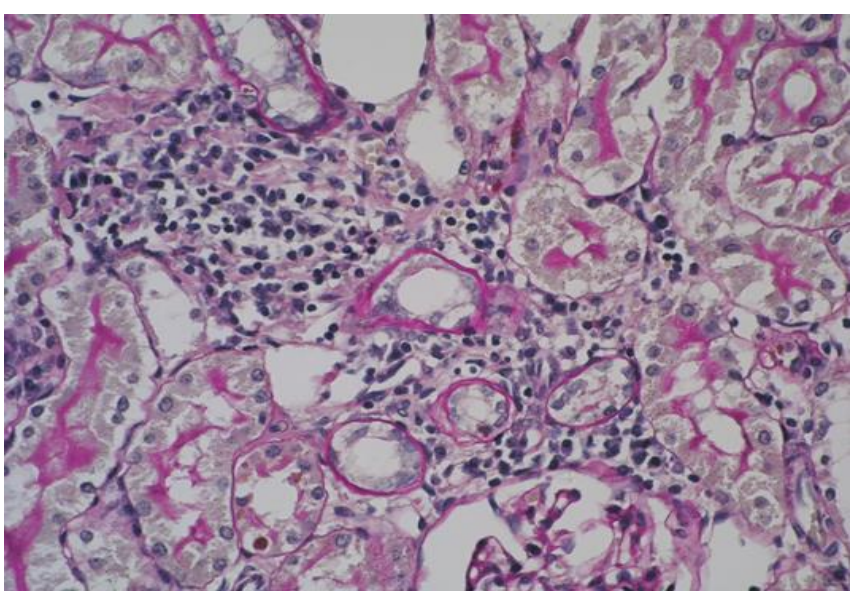

a)

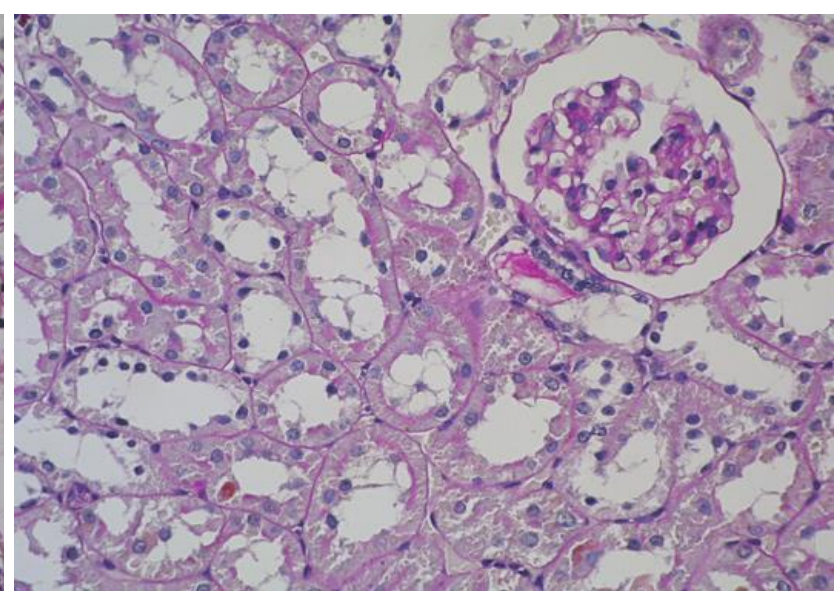

b)

Figure 3. a) Cortical labyrinth of the kidney of a female rat, which received molsidomine from ATP-LONG at a dose of $1300 \mathrm{mg} / \mathrm{kg}$. Focal mononuclear infiltration of the interstitium with atrophy of single tubules. b) Cortical labyrinth of the kidney of a male rat, that received molsidomine from ATP-LONG at a dose of $2080 \mathrm{mg} / \mathrm{kg}$. There are granules of yellow-brown pigment in some epitheliocytes of the proximal convoluted tubules. Uromodulin in the lumen of the distal tubule. Staining with Schiff-iodic acid and hematoxylin, x 400 magnification.

The adrenal glands of males, administered with doses $1300 \mathrm{mg} / \mathrm{kg}$ and $2080 \mathrm{mg} / \mathrm{kg}$ of the combination, showed noticeable spongiocytes hypertrophy in zona fasciculata as a consequence of an increase in lipid inclusions (Fig. 4), along with apparent medullary sinusoidal capillary dilation, followed with an increase, comparing with the control group, amount of cells with dystrophic features and degenerative changes, development of which could be linked with functional tension of the cells and correspondingly its rapid premature "wear off". 


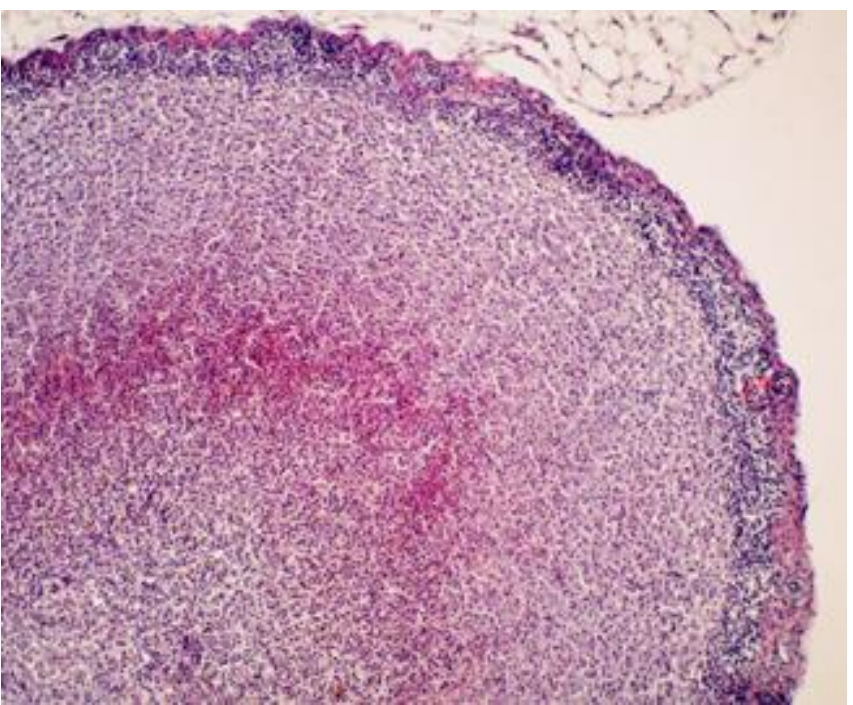

a)

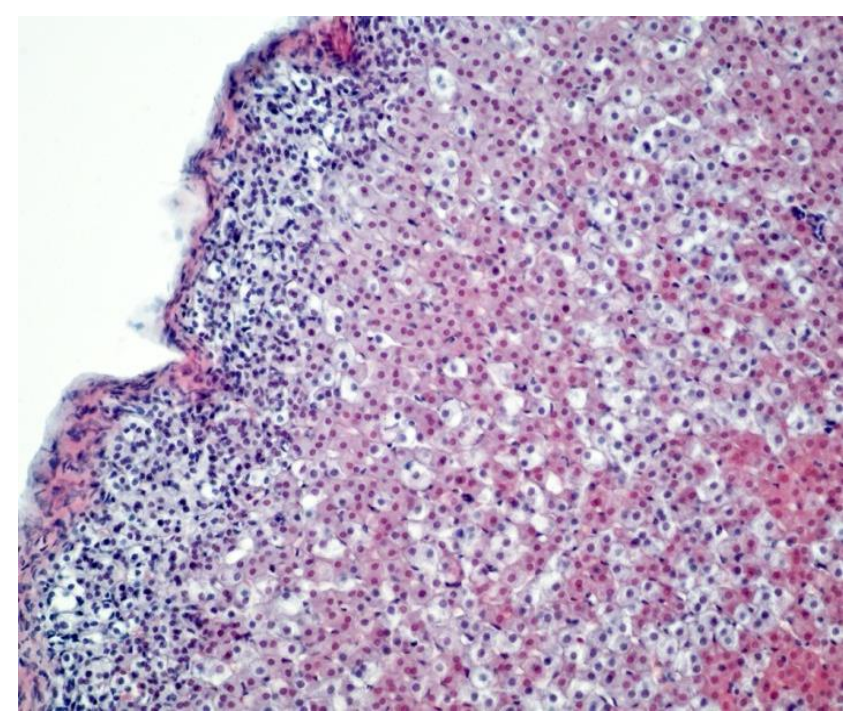

b)

Figure 4. The area of the rat adrenal gland after administration of a combination of molsidomine with ATP-LONG at a dose of $2080 \mathrm{mg} / \mathrm{kg}$ : a) hypertrophy of the cortical substance for the zona glomerulosa and zona fasiculata; c) heterogeneity of cells of the zona fasiculata, where an increase in light cells with signs of their hypertrophy is observed due to the accumulation of lipids in the cytoplasm. Hematoxylin and eosin. x 200 magnification.

The combination of molsidomine with ATP-LONG in $260 \mathrm{mg} / \mathrm{kg}$ dosage did not cause any changes in the brain's structure. There have been histological changes of hydropic nature (edema), ventricular dilation, and loss of neurons in the hippocampus after administering of 1300 and 2080 $\mathrm{mg} / \mathrm{kg}$ doses of the substance. The general feature was a significant increase in pericellular swelling, especially around neurons, more pronounced effect within the cortex and hippocampus. The structure of the neurons was preserved with the pronounced Nissl substance; however, the number of cells significantly dropped in the hippocampus. Capillaries were moderately plethoric, occasionally with swellings of the precapillary region of astrocyte processes. Ventricles of the brain were dilated, ependyma often exfoliated, vascular plexus significantly larger in size (Fig. 5).

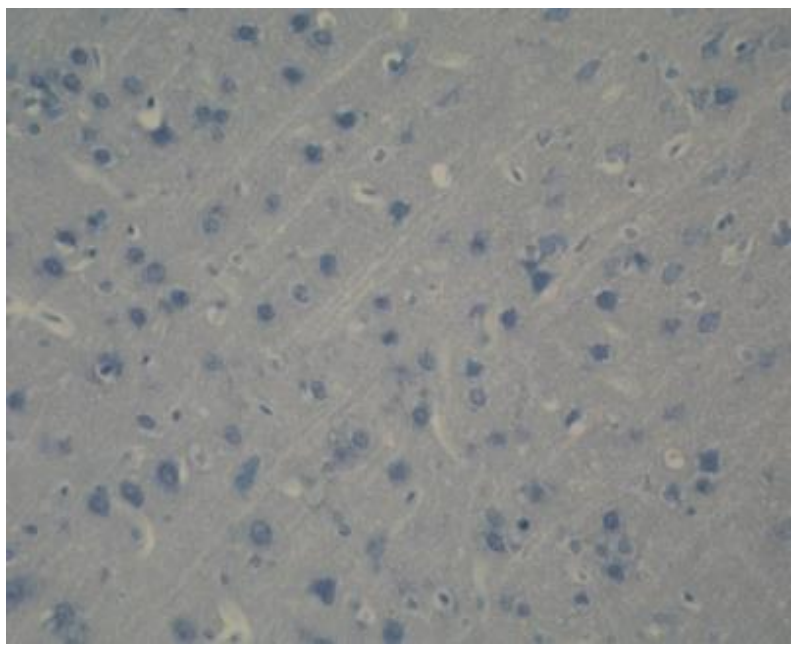

a) x 200 magnification

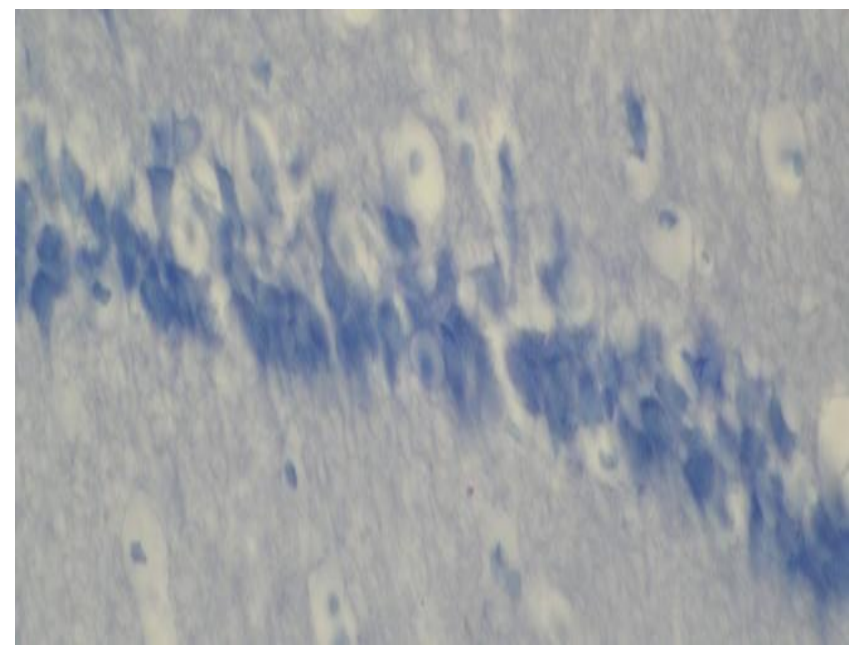

b) x 400 magnification

Figure 5. a) Sensorimotor cortex of a female rat, which received a combination of molsidomine with ATP-LONG at a dose of $2080 \mathrm{mg} / \mathrm{kg}$; b) The hippocampus of a male rat receiving the combination at a dose of $2080 \mathrm{mg} / \mathrm{kg}$. Hematoxylin and eosin. 
The study of local irritant action established that in $260 \mathrm{mg} / \mathrm{kg}$ combination of molsidomine with ATP-LONG did not cause any changes in the administration site - mucus membrane of the mouth and tongue. The rats that were administered with 1300 and $2080 \mathrm{mg} / \mathrm{kg}$, had swelling of the connective tissue and thickening of the outermost layer of an epithelial lining of mucus membrane of the tongue, which suggests an irritation action (Fig. 6).

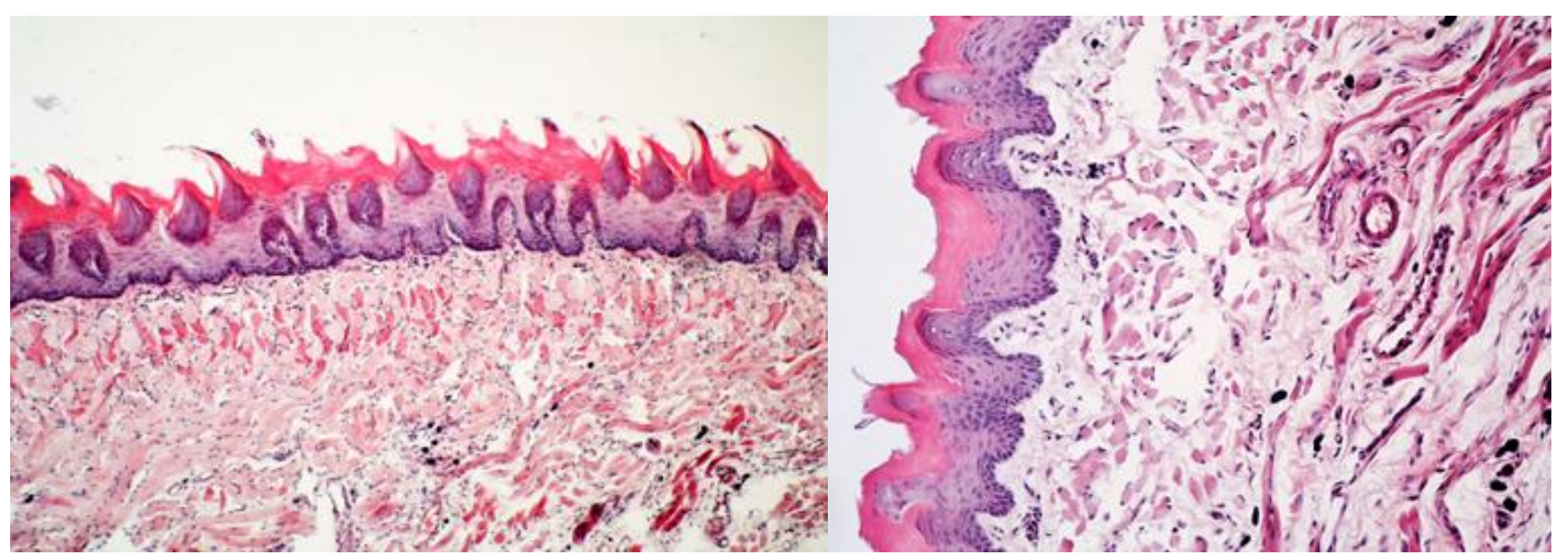

a) $x 200$ magnification

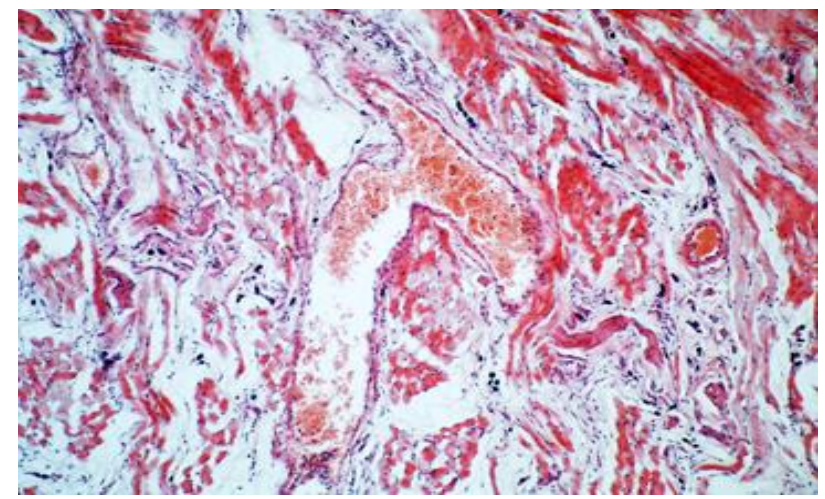

c) $x 100$ magnification

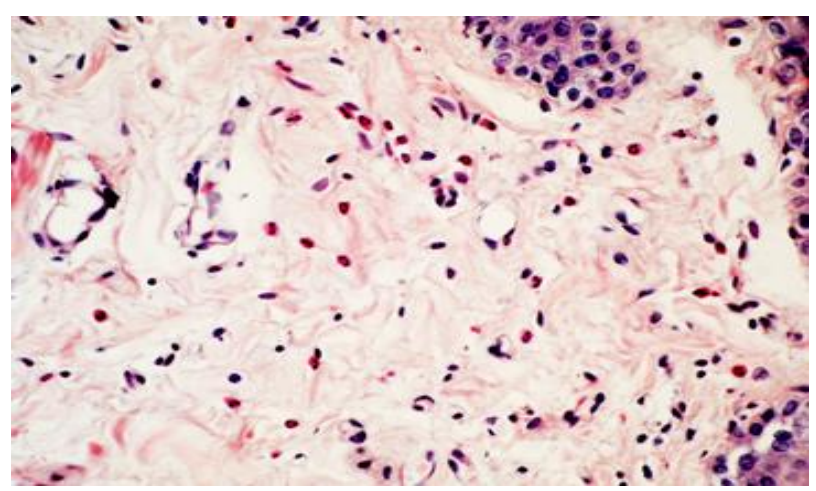

e) $x 400$ magnification b) x 200 magnification

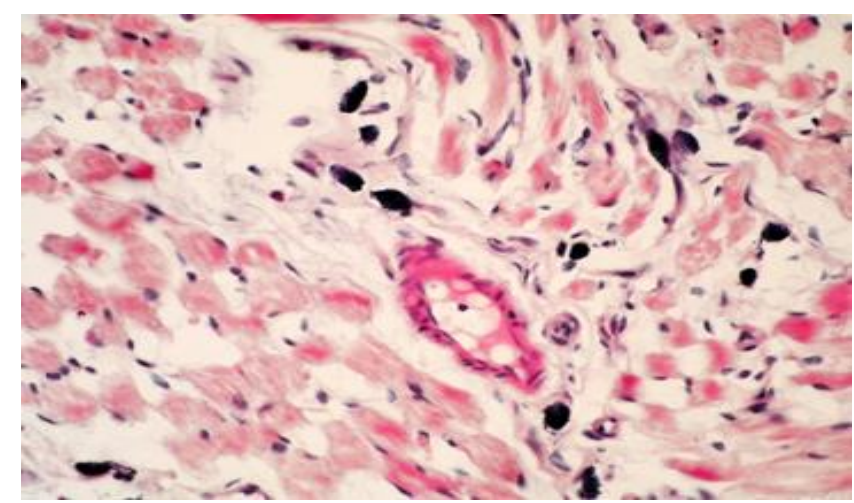

d) $x 400$ magnification

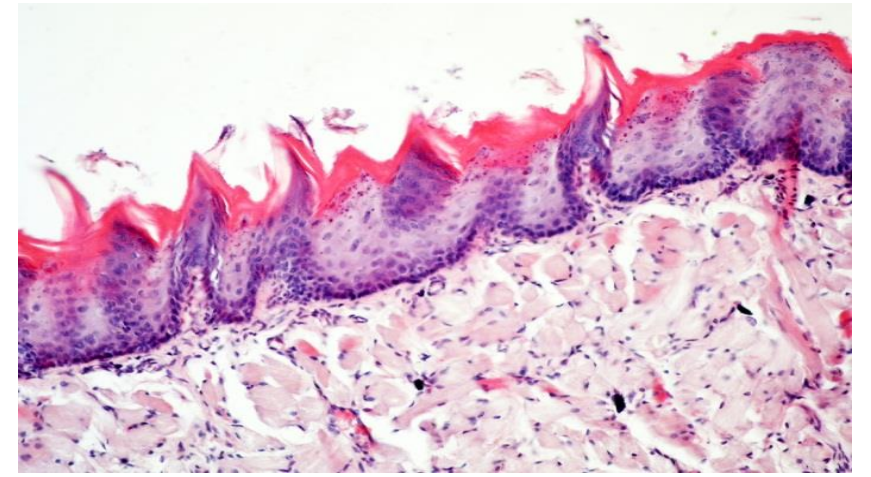

f) $x 200$ magnification

Figure 6. a) - The area of the tongue of the control rat; b) the area of the rat tongue after a dose of a combination of mosidomine with ATP-LONG $1300 \mathrm{mg} / \mathrm{kg}$ - slight swelling of the connective tissue; c) - f) - areas of the rat tongue after administration of a dose of $2080 \mathrm{mg} / \mathrm{kg}$ : c) dilation and plethora of capillaries and swelling of the connective tissue;

d) hyperplasia of tissue basophils; connective tissue swelling; e) edema and diffuse lympholeukocyte infiltration of connective tissue; f) thinning of the corneal layer at the tips of the filamentous papillae of the mucous membrane and a decrease of the number of keratohyalin granules in the cytoplasm of the epitheliocytes of the granular layer. Hematoxylin and eosin 
Analyzing the obtained data, it should be noted that the core-specific activity of molsidomine is directed at relaxation of smooth muscle cells. As a result of direct vasodilator action on coronary and other arteries and blood deposition in veins, it alleviate the burden on the heart, leading to a lesser oxygen demand for myocardium antihypoxic effect molsidomine [31]. Blood overflow of organs and swelling, detected during histological research, is a natural sequence to a specific action of molsidomine in a combination, which becomes especially evident at high doses. This is coherent with the data that excess of NO leads to an increase of vessel permeability. and swelling of the tissue; also, it may cause a direct toxic (cardiotoxic) action as a result of stable generalized vasodilation and pronounced drop of arterial pressure [31].

On the other side, we could hypothesize that undesirable effects of the preparation in doses, which significantly exceed conditionally therapeutic values, amplify in a result of a bioaccessible increase and the speed of reaching a maximal concentration of acting agents at sublingual administration, used in our studies. As it is known, sublingual doses of medical preparation form by the severity of pharmacological effect dominate over the forms, which give a gradual escalation in concentration. Because the sublingual administration enters the bloodstream 3-10 times more of the doses of a medical substance rather than with peroral [32] over a period of time, it allows for the alternative way of systemic deliverance of drugs [33]. It is still worth taking into account that a prolonged high concentration of nitric oxide may affect the balance of intracellular signaling pathways, cause activation or inhibition of ion channel proteins, changes in enzymatic activity and lead to side effects [34].

Thus, combination of molsidomine with ATP-LONG by the parameters of acute toxicity with single administration corresponds to the class of practically nontoxic substances. Additional administrations during a 28 day period with conditionally therapeutic doses of combination did not cause any adverse effect on physiological, hematological, biochemical, and histological indexes of male and female rats. In doses that exceed the conditionally therapeutic dose by 5 and 8 times, the drug did not change clinical-laboratory values of urine and blood; however, it caused changes in the structure of internal organs, which could be viewed as a specific reaction of the organism to overdose on vasodilator. Therefore, there is a necessity for a precise dose and course of molsidomine since its overdose, including in the form of combination, could lead to adverse effects with the duration and reversibility that need further research.

We express our gratitude to Shinkaryova M.Y., the director of the Pharmaceutical Company "FarKos" $L L C$, for providing test samples (substance) for the research.

Author Contributions: All authors participated equally in writing this article.

Conflicts of Interest: The authors declare no conflict of interest.

Information about Authors:

Liana P. Kuprash - DSc (Medicine), Head of the Geriatric Pharmacology Laboratory of the D. F. Chebotarev Institute of Gerontology NAMS of Ukraine; https://orcid.org/0000-0001-8196-751X

Tetyana M. Panteleymonova - PhD (Biology), Leading Researcher of the Geriatric Pharmacology Laboratory of the D. F. Chebotarev Institute of Gerontology NAMS of Ukraine; https://orcid.org/0000-0002-3606-5805

Ludmila B. Sharabura - PhD (Biology), Leading Researcher of the Geriatric Pharmacology Laboratory of the D. F. Chebotarev Institute of Gerontology NAMS of Ukraine; https://orcid.org/0000-0002-8182-7979

Sergiy A. Mykhalskiy - PhD (Biology), Leading Researcher of the Laboratory of Morphology and Cytology of the D. F. Chebotarev Institute of Gerontology NAMS of Ukraine; https://orcid.org/0000-0002-7232-4608

Pavlo P. Klymenko - PhD (Biology), Leading Researcher of the Laboratory of Morphology and Cytology of the D. F. Chebotarev Institute of Gerontology NAMS of Ukraine; https://orcid.org/0000-0001-9905-1956

Sergey P. Lugovskoy - DSc (Medicine), Leading Researcher of the Laboratory of Morphology and Cytology of the D. F. Chebotarev Institute of Gerontology NAMS of Ukraine; https://orcid.org/0000-0002-3948-7026

Valentyn M. Nepomnyashchy - PhD (Medicine), Head of the Pathology Laboratory of the Institute of Nephrology NAMS of Ukraine; https://orcid.org/0000-0002-6730-7678

Nina V. Sykalo - PhD (Biology), Leading Researcher of the Laboratory of Physiology of the D. F. Chebotarev Institute of Gerontology NAMS of Ukraine; https://orcid.org/0000-0001-7812-8504

Vladislav V. Bezrukov - MD, DSc (Medicine), Prof., Full Member (Academician) of the NAMS of Ukraine, Director of the D. F. Chebotarev Institute of Gerontology NAMS of Ukraine, Head of the Laboratory of Physiology of the D. F. Chebotarev Institute of Gerontology NAMS of Ukraine; https://orcid.org/0000-0002-3913-3818 


\section{References}

1. Kozlovsky, V.A .; Shmaliy, V.I. ATP as a messenger and messenger as a target of therapeutic influence. Liky Ukrayiny 2008, 3, 119, 48-51. (in Russian)

2. Amosova, E.N.; Bereza, N.V.; Potapkova, I.V. The effect of complex therapy with the inclusion of ATPLONG on the diastolic function of the left ventricle in patients with ischemic heart disease at rest and during isometric exercise. Likars'ka sprava 2002, 3-4, 48-50. (in Russian)

3. Herman, A.G.; Moncada, S. Therapeutic potential of nitric oxide donors in the prevention and treatment of atherosclerosis. Eur. Heart. J. 2005, 26, 1945-1955.

4. Messin, R.; Dubois, C.; Famaey, J.-P. Comparative effects of once-daily molsidomine in coronary patients from two distinct European ethnicities. Adv. Ther. 2008, 25, 11, 1200-1214.

5. Manukhina, E. B.; Malyshev I. Yu.; Archipenko, Yu. V. Nitric oxide in the cardiovascular system: a role in adaptive defense. Bulletin of the Russian Academy of Medical Sciences 2000, 4, 16-21. (in Russian)

6. Kuprash, L. P.; Panteleymonova, T. M.; Sharabura, L. B. et al. Protectoral action of molsidomine ATP combination in chronic stress in young and old rats. Ageing $\mathcal{E}$ Longevity 2020, 1, 2, 50-64. http://dx.doi.org/10.47855/jal9020-2020-2-1

7. Bezrukov, V. V.; Kuprash, L. P.; Sykalo, N. V. et al. Effect of ATP and molsidomine combination on contractile function of isolated adult and old rat hearts during adequate coronary perfusion, at ischemia and reperfusion. Ageing \& Longevity 2021, 2, 1, 16-25. https://doi.org/10.47855/jal9020-2021-2-2

8. Dunwiddie, T.V.; Masino S. A. The role and regulation of adenosine in the central nervous system. Annu Rev. Neurosci 2001, 24, 1, 31-55. https://doi.org/10.1146/annurev.neuro.24.1.31

9. Takahama, H; Minamino, T.; Asanuma, H. et al. Prolonged Targeting of Ischemic/reperfused myocardium by liposomal adenosine augments cardioprotection in rats. J. Am. Coll. Cardiol. 2009, 53, 8, 709-717.

10. Sodium adenosine triphosphate. Instructions for storing . Compendium 2009.

https://compendium.com.ua/ info/1673/natrija-adenozintrifosfat-darnitsa/ (in Russian)

11. Kazemzadeh-Narbat, M.; Annabi, N.; Tamayol, A. et al. Adenosine-Associated Delivery Systems. J Drug Target 2015, 23, 7-8, 580-596. https://doi.org/10.3109/1061186x.2015.1058803

12. Burnstok, G.; Knight, G.E.; Greig, A.V. Purinergic signaling in healthy and diseased skin. J. Invest. Dermatol. 2012, 132, 526-546. https://doi.org/10.1038/jid.2011.344

13. Coolenm E.J.; Arts, I.C.; Bekers, O. et al. Oral bioavailability of ATP after prolonged administration. Br. J. Nutr. 2011, 105, pp. 357-366. https://doi.org/10.1017/S0007114510003570

14. Deshpande, S. R.; Satyanarayana, K.; Rao, M. N.; Pai K. V. Nitric oxide modulators: An emerging class of medicinal agents. Indian J. Pharm. Sci. 2012, 74, 6, 487-497. https://dx.doi.org/10.4103\%2F0250-

474X.110572

15. Barbato, J.E.; Tzeng, E. Nitric oxide and arterial disease. J. Vasc. Surg. 2004, 40 (1), pp. 187-193. https://doi.org/10.1016/j.jvs.2004.03.043

16. Kruchinina, M.V .; Gromov, A.A .; Svetlova, I.O. et al. Erythrocytes and NO: facts, hypotheses of interaction, perspectives for diagnostics and therapy of cardiovascular diseases. Review. Atherosclerosis 2014, 10, 3, 68-80. (in Russian)

17. Smirin, B.V .; Pokidyshev, D. A .; Malyshev, I. Yu. Et al. Deposition of nitric oxide as a factor of adaptive protection. Russian Physiological Journal 2000, 4, 447-454. (in Russian)

18. Solovyova, A. G.; Kuznetsova, V. L.; Peretyagin, S.P. et al. The role of nitric oxide in the processes of free radical oxidation. Bulletin of the Russian Military Medical Academy 2016, 1, 53, 228-233. (in Russian) 19. Davis, K.L.; Martin, E.; Turko, I.V.; Murad F. Novel effects of nitric oxide. Ann. Rev. Pharmacol. Toxicol. 2001, 41, 203-230. https://doi.org/10.1146/annurev.pharmtox.41.1.203

20. Moncada, S.; Palmer, R.M.J.; Higgs, E.A. Nitric oxide: physiology, pathophysiology and pharmacology. Pharmacol. Rev. 1991, 43, 109-142.

21. Kumar, A.; Chanana, P. Role of Nitric oxide in stress-induced anxiety: from pathophysiology to therapeutic target. Vitam. Horm. 2017, 103, 147-167. https://doi.org/10.1016/bs.vh.2016.09.004

22. Bonilla, I. M.; Sridhar, A.; Nishijima, Y.et al. Differential effects of the peroxynitrite donor, SIN-1, on atrial and ventricular myocyte electrophysiology. J. Cardiovasc. Pharmacol. 2013, 61, 5, 401-407.

https://doi.org/10.1097/fjc.0b013e31828748ca 
23. Drexler, H. Nitric oxid and coronary endothelial dysfunction in humans. Cardiovasc Res. 1999, 43, 572579.

24. Task Force Members 2013. The ESC guidelines on the management of studie coronary artery disease: Task Force on the management of studie coronary artery disease of the European Society of cardiology. Eur.Yeart. J. 2013, 34, 38, 2949-3003.

25. Maggioni, A. P.; Franzosi, M. G.; Latini, R. Beta-adrenoceptor antagonists and antianginal drugs. Side Effects of Drugs Annual. 2008, 30, pp. 223-230. https://doi.org/10.1016/S0378-6080(02)80025-3

26. Sirenko, Yu. M.; Torbas, O. O. Modern symptomatic therapy for stable angina pectoris: what to choose? Hypertension 2019, 3-4, 65-66, 20-30. https://doi.org/10.22141/2224-1485.3-4.64-65.2019.177844. (in Russian)

27. Kyeong, H. J.; Euni, L. A Systematic Review on Drug Safety for Molsidomine, Nicorandil and Trimetazidine. Korean J. Clin. Pharm. 2016, 26, 2, 172-180.

28. The procedure for preclinical study of drugs and examination of materials for preclinical study of drugs. Order of the Ministry of Health of Ukraine № 944 dated 14.12., 2009, p. 18. (in Ukrainian)

29. Stefanov, O. V. Preclinical studies of drugs (guidelines): Kyiv, 2002. p. 602. (in Ukrainian)

30. Laboratory animals. Breeding, maintenance, use in the experiment. Zapadnyuk, I. P.; Zapadnyuk, V. I.; Zakhariya, E. A.; Zapadnyuk, B. V., Ed. High school: Kyiv, 1983, p. 381. (in Russian)

31. Metelskaya, V. A .; Gumanova, N. G. Nitric oxide: role in the regulation of biological functions, methods of determination in human blood. Laboratory medicine 2005, 7, 19-24. (in Russian)

32. Patel, P.; Makwana, S.; Jobanputra, U. et al. Sublingual Route for the Systemic Delivery of Ondansetron. Int. J. Drug Dev. \& Res. 2011, 3, 4, 36-44.

33. Campisi, G.; Paderni, C.; Saccone, R. et al. Human buccal mucosa as an innovative site for drug delivery. Curr. Pharm. Des. 2010, 16, 6, 641-652. https://doi.org/10.2174/138161210790883778

34. Barros, M.P.; Araujo-Chaves, J.C.; Brito, A.M.M.; Nantes-Cardoso, I.L. Oxidative/nitrative mechanism of molsidomine mitotoxicity assayed by the cytochrome $\mathrm{C}$ relaction with SIN-1 in models of biological membranes. Chem. Res. Toxicol. 2020, 33, 11, pp. 2775-2784. https://doi.org/10.1021/acs.chemrestox.0c00122. 